\title{
РЕГІОНАЛЬНА ПОЛІТИКА ТА РОЗВИТОК СІЛЬСЬКИХ ТЕРИТОРІЙ НА СУЧАСНОМУ ЕТАПІ СТАНОВЛЕННЯ УКРАЇНСЬКОЇ ДЕРЖАВИ
}

У дослідженні розглядаються принциии державної регіональної політики та практичні аспекти публічного управління в інноваційному розвитку сільських територій на сучасному етапі становлення Української держави. Виокремлюються основні принципи дослідження місия $i$ ролі сільських територіальних громад у розвитку територій. Визначаються теоретико-методологічні основи публічного управління розвитком сільських територій на інноваційних засадах у сучасних умовах економіко-адміністративного управління. Установлюється, щуо для досягнення мети інноваційної політики публічного управління сільською територією першочерговим завданням є формування пріоритетів стратегічної діяльності. Наголошено, щьо ефективну стратегію державної регіональної політики буде можливо розробити лише після проведення чергового перепису населення (лютий 2023 року), систематизації демографічних та економічних тенденцій. При цььому слід відмовитися від ідеї угод між Кабінетом Міністрів України та обласними радами. Замість того, органи місиевого самоврядування мають мати можливість ініціювати проєкти розвитку окремих територій, а кінцеве рішення має ухвалювати Уряд, що відповідає за формування державної регіональної політики. Крім того, треба відмовитися від ідеї запровадження будь-яких податкових пільг, щчо мають прив'язку до окремих територій. На сьогодні вже розробляються принципові заходи політики публічного управління інноваційним розвитком сільських територій. У статті резюмується, щзо політика публічного управління розвитком сільських територій має трунтуватися на концентрації зусиль $i$ коштів, спрямованих на інноваційний розвиток інституту місцевого самоврядування як основи розвитку сільських територій.

Ключові слова: Українська держава, регіональна політика, розвиток сільських територій, децентралізаџія влади, місцеве самоврядування, громадянське суспільство.

И.П. ЛОПУШИНСКИЙ

Херсонский национальный технический университет ORCID: 0000-0002-7460-7476

В.Д. ФИЛИППОВА

Херсонский национальный технический университет ORCID: 0000-0002-8476-3341

Р.М. ПЛЮЩ

Херсонский национальный технический университет ORCID: 0000-0003-1135-1482

\section{РЕГИОНАЛЬНАЯ ПОЛИТИКА И РАЗВИТИЕ СЕЛЬСКИХ ТЕРРИТОРИЙ НА СОВРЕМЕННОМ ЭТАПЕ СТАНОВЛЕНИЯ УКРАИНСКОГО ГОСУДАРСТВА}

В исследовании рассматриваются принципь государственной региональной политики $и$ практические аспекты публичного управления инновационным развитием сельских территорий на современном этапе становления Украинского государства. Выделяются основные принципь исследования места и роли сельских территориальных общиин в развитии территорий. Определяются теоретико-методологические базы общественного управления развитием сельских территорий на инновационных принципах в современных условиях экономико-административного управления. Установлено, что для достижения цели инновационной политики публичного управления сельской территорией первоочередной задачей является формирование приоритетов стратегической деятельности. Отмечено, что эффективную стратегию государственной региональной политики будет возможно разработать только после проведения очередной переписи населения (февраль 2023), систематизации демографических и экономических тенденций. При этом следует отказаться от идеи соглашений между Кабинетом Министров Украины и областными советами. Вместо этого органь 
местного самоуправления должны иметь возможность инициировать проекты развития отдельных территорий, а конечное решение должно принимать Правительство, отвечающее за формирование государственной региональной политики. Кроме того, нужно отказаться от идеи введения каких-либо налоговых льгот, имеюших привязку $к$ отдельным территориям. На сегодняшний день уже разрабатываются принципиальные меры политики публичного управления инновационным развитием сельских территорий. В статье резюмируется, что политика публичного управления развитием сельских территорий основывается на концентрацчии усилий и средств, направленных на инновационное развитие института местного самоуправления как основы развития сельских территорий.

Ключевые слова: Украинское государство, региональная политика, развитие сельских территорий, децентрализаџия власти, местное самоуправление, гражданское общество.

I. P. LOPUSHYNSKYI

Kherson National Technical University ORCID: 0000-0002-7460-7476

V.D. FILIPPOVA

Kherson National Technical University ORCID: 0000-0002-8476-3341

R. M. PLIUSHCH

Kherson National Technical University ORCID: 0000-0003-1135-1482

\section{REGIONAL POLICY AND DEVELOPMENT OF RURAL AREAS AT THE PRESENT STAGE OF FORMATION OF THE UKRAINIAN STATE}

The principles of the state regional policy and practical aspects of public management of innovative development of rural areas at the modern stage of formation of the Ukrainian state are considered in the research. The basic principles of the place and role of rural territorial communities in the development of territories are singled out. Theoretical and methodological bases of public management of rural development on innovative principles in modern conditions of economic-administrative management are determined. It is established that in order to achieve the goal of innovation policy of public administration of rural territories the priority task is the formation of priorities of strategic activity. It is noted that an effective strategy of public regional policy will be possible to develop only after the next census (February 2023), systematization of demographic and economic trends. The idea of agreements between the Cabinet of Ministers of Ukraine and regional councils should be abandoned. Instead, local self-government bodies should be able to initiate development projects for their territories, and the government, which is responsible for shaping state regional policy, should take the final decision. In addition, the idea of introducing any tax incentives linked to certain areas should be abandoned. To date, the principal measures of the policy of public management of innovative development of rural areas are already being developed. The article summarizes that the policy of public administration of rural development is based on the concentration of efforts and means aimed at innovative development of the local government institution as the basis of rural development.

Key words: Ukrainian state, regional policy, rural development, power decentralization, local selfgovernment, civil society.

\section{Постановка проблеми}

Як відомо, важливою складовою регіональної політики є соціально-економічний розвиток сільських територій. Сучасний економічний стан нашої держави продовжує залишатися складним, проте останнім часом уже накреслилися шляхи до його суттєвого поліпшення. Кількість заходів, що здійснюються нині державною і місцевою владою в межах державної політики в цій сфері, починає набувати ознаки значного впливу на ситуацію. Водночас процес розвитку сільських територій України характеризується суттєвими відмінностями за рівнем їх соціально-економічного розвитку, державою і місцевим самоврядуванням недостатньо чітко визначено стратегію розвитку регіонів і сільських територій, наразі ще відчувається певна неузгодженість законодавчих та нормативно-правових актів, особливо з актами органів місцевого самоврядування. В умовах сьогодення залишаються актуальними проблеми формування та реалізації державної політики, створення та регулювання механізмів управління розвитком сільських територій, розподілу основних повноважень між органами державної влади та органами місцевого самоврядування. Означене вище, як нам видається, і є тими основними причинами, що зумовлюють потребу пошуку та формування ефективних механізмів функціонування та розвитку сільських територій України. Ці питання, на наше глибоке переконання, потребують дальшого вивчення як на регіональному, місцевому, так і на державному рівні.

Аналіз останніх досліджень і публікацій

Останнім часом до проблеми регіональної політики та розвитку сільських територій у вітчизняному науковому дискурсі зверталися С. Белей [1], В. Белявцева [2], В. Готра, А. Ковач [3], 
В. Мельник, Н. Добіжа, О. Погріщук [6], С. Приліпко [7; 8], М. Талавиря, О. Грай [12] та ін. Як видно, актуальність питань специфіки публічного управління у сфері розвитку сільських територій останнім часом активізувала відповідні дослідження в цьому напрямку, основним завданням яких є обгрунтування методики інноваційного розвитку сільських територіальних громад 3 урахуванням забезпечення належного рівня якості життя, підвищення статусу та ролі сільського населення. Водночас, дослідивши наукові джерела, ми виявили значні прогалини в проведенні політики публічного управління щодо розвитку сільських територій. Отже, означена проблематика вимагає дальших поглиблених наукових досліджень, у тому числі і в науці державного управління.

\section{Формулювання мети дослідження}

Саме тому метою нашого дослідження й стало дослідження теоретичних засад та практичних аспектів публічного управління інноваційним розвитком сільських територій. Теоретичною та методологічною основою досліджень $є$ основні положення та розробки вітчизняних учених і зарубіжний досвід 3 проблем теорії та практики публічного управління, особисті оцінки авторів.

\section{Викладення основного матеріалу}

Розвиток сільських територій $є$ важливим об’єктом державної регіональної політики з огляду на ïx функціональне призначення та забезпечення просторо-економічного розвитку країни. Нагромадження та загострення наявних проблем ї розвитку свідчить про низьку ефективність та здебільшого декларативний характер більшості ухвалених упродовж останніх тридцяти років (1991 - 2021 рр.) нормативно-правових актів (концепцій, програм тощо), що торкалися питань розвитку села, сільської місцевості, сільських територій.

Отже, інституційне середовище функціонування сільських територій досі не сформовано, остаточна законодавча невизначеність щодо проведення земельної та адміністративної реформ, правового статусу майна, що належало до спільної власності територіальних громад тощо стають перепонами на шляху до формування чітких пріоритетів і цілей розвитку сільських територій. Така ситуація призвела до тривалого зростання безробіття на селі, збільшення міграційних потоків 3 села в міста і за кордон, простоювання та деградації значних обсягів сільськогосподарських земель, почасти їх незаконне використання, спричинене неналежним їх обліком, зосередження вагомої частки земельних ресурсів в агрохолдингах тощо.

Саме тому в основу реалізації ухваленої цього року Державної стратегії регіонального розвитку на 2021-2027 роки [10] покладено комплексний територіальний підхід, що передбачає «застосування особливих механізмів та інструментів державної підтримки» залежно від типу функціональної території. Одним із типів територій, що потребують особливої уваги з боку держави та застосування спеціальних механізмів та інструментів стимулювання ї розвитку, визначено сільські території в несприятливих умовах. 3 огляду на обмежені можливості працевлаштування сільських мешканців та функціонування неформального сектору зайнятості, що є здебільшого основним джерелом їх доходів, необхідним постає створення передумов для стимулювання розвитку інших видів економічної діяльності, альтернативних веденню сільського господарства.

Важливим чинником розвитку сільської території та ії ціллю водночас є диверсифікація сільської економіки зважаючи на превалюючий на сьогодні монофункціональний розвиток сільських територій та високу частку зайнятого населення саме в сільському господарстві (близько $35 \%$ ). Така ситуація зумовлює потребу пошуку нових ефективних механізмів та інструментів забезпечення багатофункціонального розвитку сільських територій із урахуванням впливу такого чинника, як децентралізація.

Таким чином, обгрунтування теоретико-методологічних засад та розроблення практичних рекомендацій щодо організаційно-економічного забезпечення диверсифікації розвитку сільських територій в умовах децентралізації є надзвичайно актуальним.

Як відомо, державна регіональна політика - система цілей, заходів, засобів та узгоджених дій центральних і місцевих органів виконавчої влади, органів місцевого самоврядування та їх посадових осіб для забезпечення високого рівня якості життя людей на всій території України з урахуванням природних, історичних, екологічних, економічних, географічних, демографічних та інших особливостей регіонів, їх етнічної і культурної самобутності [9].

Регіональний розвиток - процес соціальних, економічних, екологічних, гуманітарних та інших позитивних змін у регіонах [9] Метою державної регіональної політики $є$ створення умов для динамічного, збалансованого розвитку України та ії регіонів, забезпечення їх соціальної та економічної єдності, підвищення рівня життя населення, дотримання гарантованих державою соціальних стандартів для кожного громадянина незалежно від його місця проживання [9].

Як зазначається в Енциклопедії державного управління, сільські території - це гетерогенні за своєю структурною будовою соціально-просторові утворення, що складаються з населення, поселень, виробничих комплексів, інфраструктури, земель сільськогосподарського та іншого призначення, природного середовища [5, с. 355]. Сільські території знаходяться під управлінським впливом державної 
влади, органів місцевого самоврядування, громадських організацій, а також суб’єктів господарювання різних форм власності, що виконують виробничо-господарські, природоохоронні, рекреаційно-оздоровчі, соціальні та інші функції з урахуванням їх ресурсного потенціалу [5, с. 355].

Як об’єкт функціонування й управління сільські території складаються з базового, районного, регіонального та загальнодержавного рівнів, що співвідносяться між собою за принципом «мотрійки» $[5$, c. 355].

3 огляду на специфічні властивості та риси сільських територій, вони класифікуються за такими критеріями: ступінь ресурсозабезпеченості, вид на режим використання території, політико-правовий статус, домінантна функція, рівень урбанізації, ступінь розвитку, значення та масштаб функцій, етична ознака тощо [5, с. 355].

Далі звернемося до розкриття такого поняття, як сталий розвиток, що наразі має першочергове значення для розвитку територій, у тому числі й сільських. Енциклопедичний словник 3 державного управління подає таке визначення сталого розвитку. Це «концепція, згідно з якою природні ресурси планети мають використовуватися людством за умови збереження навколишнього середовища та забезпечення потреб наступних поколінь у ресурсах» [4, с. 672]. За визначенням Комісії ООН зі сталого розвитку, його мета - задовольняти потреби сучасного суспільства, не ставлячи під загрозу здатність майбутніх поколінь задовольняти власні потреби $[4$, с. 625$]$. Зокрема, здійснення управління розвитком населених пунктів на засадах сталого розвитку вимагає від органів державної влади та органів місцевого самоврядування впровадження інноваційних технологій у містобудівній діяльності, управлінні комунальним майном, наданні управлінських послуг тощо [4, с. 625].

Як відомо, у серпні 2020 року Кабінет Міністрів України затвердив Державну стратегію регіонального розвитку на 2021-2027 роки [10]. Таким чином було визначено типи територій, що потребують державної підтримки, та основні напрямки державної регіональної політики. Серед них, зокрема: відновлення територій, уражених бойовими діями, розвиток сільських територій та посилення інтегрувальної ролі великих агломерацій.

9 червня 2021 року Кабінет Міністрів України схвалив законопроєкт [11] відносно особливостей стимулювання регіонального розвитку, що, без перебільшення, впливатиме на життя кожного українця, оскільки в ньому йдеться про інноваційні підходи держави до регіональної політики та розвитку територій.

Названий проєкт Закону щодо особливостей стимулювання регіонального розвитку [11] розроблено на виконання Указів Президента України «Про невідкладні заходи щодо забезпечення економічного зростання, стимулювання розвитку регіонів та запобігання корупції» та «Про невідкладні заходи 3 проведення реформ та зміцнення держави», а також Плану пріоритетних дій Уряду на 2021 рік та Плану законопроєктної роботи Верховної Ради України на 2021 рік.

Законопроєкт [11] урегульовує підходи держави до підтримки різних типів територій. Зокрема тих, які мають обмежені можливості для розвитку: рідконаселена сільська та гірська місцевість, прифронтові території, прикордонні території з РФ та Молдовою, колишні центри добувної промисловості, що наразі знаходяться в стадії стагнації.

Для стимулювання розвитку таких територій планують: спрямувати кошти на розвиток виробничої (у тому числі створення індустріальних парків), транспортної та соціальної інфраструктури, підтримувати мале та середнє підприємництво, компенсувати їм відсотки за кредитами в разі створення робочих місць, на пільгових умовах оподатковувати новий бізнес, стимулювати трудову міграцію на такі території, стимулювати перероблення сільськогосподарської продукції.

Для реалізації пріоритетів державної політики Закон, у разі його ухвалення Верховною Радою України, дозволить Кабінету Міністрів України укладати угоди щодо регіонального розвитку із Верховною Радою Автономної Республіки Крим, обласними радами, Київською та Севастопольською міськими радами. Він також дозволить відповідним радам укладати договори між собою щодо: міжрегіонального співробітництва економічного розвитку, поводження з побутовими відходами, роботи транспорту, що забезпечує жителів суміжних регіонів, збереження історичної спадщини та довкілля.

Вдалим у законопроєкті [11], на нашу думку, є те, що він пропонує комплексний підхід до розвитку територій у межах єдиної державної стратегії регіонального розвитку. Проєкт є спробою відійти від старого неефективного підходу до підтримки регіонів та окремих місцевостей, що передбачав безсистемні державні інвестиції в окремі об’єкти здебільшого державної та комунальної власності; він пропонує запровадити поділ територій залежно від економічних, демографічних, соціальних та безпекових чинників та визначити щодо кожної із них окремий підхід відносно пріоритетних напрямків розвитку та державної підтримки; створює умови для координації зусиль державної влади та органів місцевого самоврядування з метою стимулювання розвитку територій; дозволяє укладати договори між регіонами для вирішення спільних проблем.

Водночас, як нам видається, законопроєкт певною мірою порушує Конституцію України, оскільки договірний тип взаємин між центральною та місцевою владою властивий окремим 
федеральним, але не унітарним державам. Запровадження угод між Урядом і місцевою владою може стати черговим кроком у процесі федералізації країни. Це становить загрозу територіальній цілісності держави в умовах складного безпекового середовища України. Слід осібно зазначити, що близьку до запропонованої в проєкті систему угод між урядом і місцевою владою містить Закон про особливості самоврядування в ОРДЛО, нав’язаний Україні Росією під час укладення Мінських угод.

Крім того, спільні угоди Кабінету Міністрів України та обласних рад створять складну систему політичного керівництва окремими проєктами, а також розпорошать відповідальність у разі неуспішної реалізації цього проєкту та Державної стратегії регіонального розвитку, що містить зонування територій; його розроблено на основі застарілих даних про демографічну ситуацію в Україні, оскільки останній перепис населення проводився аж 2001 року. Саме тому, імовірно, що зонування територій буде неточним, а обраний перелік заходів неефективним.

На нашу думку, запропонований проєкт Закону [11] певною мірою є декларативним, а плановані заходи часто видаються нам нереалістичними. Наприклад, міграція мешканців в, а не 3 депресивних регіонів за підтримки держави; запровадження пільгового оподаткування разом зі збільшенням державного інвестування в окремі місцевості може призвести до таких же наслідків, як запровадження вільних економічних зон в 1990-их роках. Така державна політика стимулювала тоді появу олігархів, нецільове використання публічних фінансів та корупцію; є високі ризики, що без збільшення прозорості і парламентського контролю за ухваленням рішень відносно стимулювання регіонального розвитку відповідні зміни стимулюватимуть корупцію та неефективне використання публічних ресурсів.

Водночас, на наше глибоке переконання, ефективну стратегію державної регіональної політики буде можливо розробити лише після проведення чергового перепису населення (лютий 2023 року), систематизації демографічних та економічних тенденцій. Слід відмовитися від ідеї угод між Кабінетом Міністрів України та обласними радами. Замість того, органи місцевого самоврядування мають мати можливість ініціювати проєкти розвитку окремих територій, а кінцеве рішення має ухвалювати Уряд, що відповідає за формування державної регіональної політики. Крім того, треба відмовитися від ідеї запровадження будь-яких податкових пільг, що мають прив’язку до окремих територій.

\section{Висновки}

3 огляду на важливість територій для світової та національних економічних систем постала нагальна потреба аналізу їх стану й характеристики тенденцій їх розвитку в сучасних умовах українського державотворення, спричиненого проведенням децентралізації та конституційно закріпленого курсу на євроінтеграцію України. До переваг децентралізації можна віднести підвищення ефективності використання внутрішньо-господарського потенціалу територіальних громад. На наше глибоке переконання, децентралізація може підвищити ефективність дій як регіональної, так і місцевої влади, спрямованих на розвиток тих чи інших територій. Як нам видається, важливим викликом сьогодення для децентралізації є усвідомлення ролі громадськості, місцевих ініціатив у процесах інтеграції цих ініціатив для формування цілого. Таким чином, виникає потреба реорганізації фінансовоекономічного забезпечення державного управління розвитком територій України, а також змін у бюджетно-фіскальній політиці. Отже, як видно, перспективи розвитку територій є. Вони насамперед полягають у децентралізації публічної влади, що має створити нові можливості для місцевого самоврядування; сприяти вдосконаленню регіональної політики, здатності регіональних органів державної влади, органів місцевого самоврядування до розширення спектрів застосовуваних методів управління соціально-економічного процесами, активізації місцевого населення та громадянського суспільства в пошуку шляхів залучення позабюджетних (альтернативних) коштів для забезпечення розвитку сільських територій. Розвиток місцевого самоврядування, децентралізація влади та передача ресурсів і повноважень на місця в межах проведення реформи має сприяти насамперед підвищенню фінансової спроможності, інвестиційної привабливості територій та створенню умов для якісного й комфортного проживання населення.

\section{Список використаної літератури}

1. Белей С.І. Розвиток сільських територій в умовах децентралізації. Ефективна економіка, 2021. № 1. URL: http://nbuv.gov.ua/UJRN/efek_2021_1_33

2. Белявцева В.В. Становлення інституту місцевого самоврядування в Україні та його вплив на розвиток територій . Проблеми системного підходу в економіці, 2019. Вип. 1 (1). C. 58-64. URL: http://nbuv.gov.ua/UJRN/PSPE_print_2019_1(1)_11

3. Готра В. В., Ковач А. Я. Вплив процесу децентралізації на розвиток сільських територій. Науковий вісник Ужгородського університету. Серія : Економіка, 2021. Вип. 1. C. 30-37. URL: http://nbuv.gov.ua/UJRN/Nvuuec_2021_1_5

4. Енциклопедичний словник з державного управління / уклад. : Ю. П. Сурмін, В. Д. Бакуменко, А. М. Михненко та ін.; за ред. Ю. В. Ковбасюка, В. П. Трощинського, Ю. П. Сурміна. К.: НАДУ, 2010. $820 \mathrm{c}$. 
5. Енциклопедія державного управління: у 8 т. / Нац. акад. держ. упр. при Президентові України; наук.-ред. колегія: Ю. В. Ковбасюк (голова) та ін. Т. 5.: Територіальне управління / наук.-ред. колегія О. Ю. Амосов (співголова), О. С. Ігнатенко (співголова) та ін.; за ред. О. Ю. Амосова, О. С. Ігнатенка, А. О. Кузнецова. Х.: Вид-во ХарРІДУ НАДУ «Магістр», 2011. 408 с.

6. Мельник В., Добіжа Н., Погріщук О. Економічний розвиток сільських територій у концепції формування конкурентоспроможності регіонів. Вісник Тернопільського національного економічного університету, 2019. Вип. 1. С. 70-80. URL: http://nbuv.gov.ua/UJRN/Vtneu_2019_1_8

7. Приліпко С.М. Інноваційний розвиток обслуговуючої кооперації сільських територій: публічноуправлінський аспект. Державне управління та місцеве самоврядування, 2018. Вип. 2. С. 102108. URL: http://nbuv.gov.ua/UJRN/dums_2018_2_16

8. Приліпко С.М. Публічне управління розвитком територій на основі реалізації проєктів державно-приватного партнерства на засадах сталого розвитку. Державне управління: удосконалення та розвиток, 2020. № 2. URL: http://nbuv.gov.ua/UJRN/Duur_2020_2_4

9. Про засади державної регіональної політики: Закон України від 05 лютого 2015 року № 156VIII. URL: https://zakon.rada.gov.ua/laws/show/156-19\#Text

10. Про затвердження Державної стратегії регіонального розвитку на 2021-2027 роки: постанова Кабінету Міністрів України від 5 серпня 2020 р. № 695. URL: https://zakon.rada.gov.ua/laws/show/6952020-\%D0\%BF\#Text

11. Про особливості стимулювання регіонального розвитку: проєкт Закону, зареєстрований у Верховній Раді України, реєстраційний № 5649 від 10 червня 2021 року URL: http://w1.c1.rada.gov.ua/pls/zweb2/webproc4_1?id=\&pf3511=72199

12. Талавиря М. П., Горай А. О. Розвиток сільських територій в умовах децентралізації. Економіка АПК, 2018. № 11. C. 75-79. URL: http://nbuv.gov.ua/UJRN/E_apk_2018_11_11

\section{References}

1. Belei S.I. Rozvytok silskykh terytorii v umovakh detsentralizatsii. Efektyvna ekonomika, 2021. № 1. URL: http://nbuv.gov.ua/UJRN/efek_2021_1_33

2. Beliavtseva V.V. Stanovlennia instytutu mistsevoho samovriaduvannia v Ukraini ta yoho vplyv na rozvytok terytorii. Problemy systemnoho pidkhodu $v$ ekonomitsi, 2019. Vyp. 1 (1). S. 58-64. URL: http://nbuv.gov.ua/UJRN/PSPE_print_2019_1(1)_11

3. Hotra V. V., Kovach A. Ya. Vplyv protsesu detsentralizatsii na rozvytok silskykh terytorii. Naukovyi visnyk Uzhhorodskoho universytetu. Seriia : Ekonomika, 2021. Vyp. 1. S. 30-37. URL: http://nbuv.gov.ua/UJRN/Nvuuec_2021_1_5

4. Entsyklopedychnyi slovnyk $z$ derzhavnoho upravlinnia / uklad. : Yu. P. Surmin, V. D. Bakumenko, A. M. Mykhnenko ta in.; za red. Yu. V. Kovbasiuka, V. P. Troshchynskoho, Yu. P. Surmina. K.: NADU, 2010. $820 \mathrm{~s}$.

5. Entsyklopediia derzhavnoho upravlinnia: u 8 t. / Nats. akad. derzh. upr. pry Prezydentovi Ukrainy; nauk.-red. kolehiia: Yu. V. Kovbasiuk (holova) ta in. T. 5.: Terytorialne upravlinnia / nauk.-red. kolehiia O. Yu. Amosov (spivholova), O. S. Ihnatenko (spivholova) ta in.; za red. O. Yu. Amosova, O. S. Ihnatenka, A. O. Kuznetsova. Kh.: Vyd-vo KharRIDU NADU «Mahistr», 2011. 408 s.

6. Melnyk V., Dobizha N., Pohrishchuk O. Ekonomichnyi rozvytok silskykh terytorii u kontseptsii formuvannia konkurentospromozhnosti rehioniv. Visnyk Ternopilskoho natsionalnoho ekonomichnoho universytetu, 2019. Vyp. 1. S. 70-80. URL: http://nbuv.gov.ua/UJRN/Vtneu_2019_1_8

7. Prylipko S.M. Innovatsiinyi rozvytok obsluhovuiuchoi kooperatsii silskykh terytorii: publichnoupravlinskyi aspekt. Derzhavne upravlinnia ta mistseve samovriaduvannia, 2018. Vyp. 2. S. 102-108. URL: http://nbuv.gov.ua/UJRN/dums_2018_2_16

8. Prylipko S.M. Publichne upravlinnia rozvytkom terytorii na osnovi realizatsii proiektiv derzhavnopryvatnoho partnerstva na zasadakh staloho rozvytku. Derzhavne upravlinnia: udoskonalennia ta rozvytok, 2020. № 2. URL: http://nbuv.gov.ua/UJRN/Duur_2020_2_4

9. Pro zasady derzhavnoi rehionalnoi polityky: Zakon Ukrainy vid 05 liutoho 2015 roku № 156-VIII. URL: https://zakon.rada.gov.ua/laws/show/156-19\#Text

10. Pro zatverdzhennia Derzhavnoi stratehii rehionalnoho rozvytku na 2021-2027 roky: postanova Kabinetu Ministriv Ukrainy vid 5 serpnia 2020 r. № 695. URL: https://zakon.rada.gov.ua/laws/show/695-2020$\%$ D0\%BF\#Text

11. Pro osoblyvosti stymuliuvannia rehionalnoho rozvytku: proiekt Zakonu, zareiestrovanyi u Verkhovnii Radi Ukrainy, reiestratsiinyi № 5649 vid 10 chervnia 2021 roku URL: http://w1.c1.rada.gov.ua/pls/zweb2/webproc4_1?id=\&pf3511=72199

12. Talavyria M. P., Horai A. O. Rozvytok silskykh terytorii v umovakh detsentralizatsii. Ekonomika APK, 2018. № 11. S. 75-79. URL: http://nbuv.gov.ua/UJRN/E_apk_2018_11_11 